\title{
New Financial Instruments in Indian Financial System
}

\author{
K. Subramanyam Naidu \\ Asst. Professor, Dept. of Economics, S.V. Arts College, Tirupati, Andhra Pradesh
}

\begin{abstract}
The Indian financial system has undergone a significant transformation in the 1990s. the deregulation of lending rates, free pricing of equity issues, entry of private sector institutional investors including foreign institutional investors, opening up of the banking sector to the private sector, allowing Indian companies to directly tap the foreign capital markets, and so on are some of the major reforms which have changed the scenario of the Indian financial system. This new found freedom has increased competition in the Indian corporate sector. This paper aimed at the main objectives of new financial instruments such as floating rate bonds, Zero interest bonds, deep discount bonds, revolving under writing finance facility, auction rated debentures, secured premium notes with detachable and separately tradable warrants, fully convertible debentures with interest, differential shares, securitized paper, collateralized debt obligations and inverse float bonds, perpetual bonds and municipal bonds.
\end{abstract}

Keywords: Floating Rate Bonds, Zero Interest Bonds, Deep Discount Bonds, Auction Rated Debentures, Differential Shares, Securitized Papers, Pass Through Certificates, Collateralized Debt Obligations.

\section{INTRODUCTION}

\section{"A financial instrument is any contract that gives rise to a financial asset of one entity and a financial liability or equity instrument of another entity."}

- The Association of Chartered Certified Accountants (ACCA)

What is a New Financial Instrument?

A new financial instrument may be one which has some new features in the terms of agreement, when compared with the features of presently available instruments. Very few financial instruments are completely new products. Many are just new features added to the conventional financial instruments to make them marketable. The conventional financial instruments are equity shares, preference shares, debentures - partly convertible, fully convertible, and non-convertible. When certain new features like attaching a warrant to the non-convertible portion of a debenture are added, a conventional instrument turns into a new instrument.

The capital market is an important source of meeting the growing long-term financial requirements of corporates, both in private and public sectors. On the one hand, due to the colossal fund requirements of both corporates and financial institutions, the competition has become intense among the various classes of issuers to corner a share of the investors' funds, and on the other hand, investors are proving to be increasingly finicky and savvy. Hence, to cater to the differing requirements of both issuers and investors, it has become essential for issuers (borrowers) to innovate and design new financial instruments. Financial engineering has been at the back of these innovations, which have revolutionalised the business world.

A new financial instrument may be one which has some new features in the terms of agreement, when compared with the features of presently available instruments. Very few financial instruments are completely new products. Many are just new features added to the conventional financial instruments to make them marketable. The conventional financial instruments are equity shares, preference shares, debentures - partly convertible, fully convertible, and non-convertible. When certain new features like attaching a warrant to the non-convertible portion of a debenture are added, a conventional instrument turns into a new instrument.

1. Main Reasons for Innovations in Financial Instruments

- Every product needs constant re-engineering. Moreover, it has to be tailored according to the needs of the consumers. The investment environment does not get a boost if there are repeated offerings of the same product. Hence, new designs of financial products are always needed.

- The interest rates had declined and this trend forced the corporate world to think of new financial instruments.

- Investors also prefer not to be saddled with long-term instruments. Hence, instruments with varying maturity periods and with various put and call options are preferred.

- The old trend of getting finance from financial institutions has changed. Now companies prefer the capital market as a source of finance. To successfully tap capital markets, companies are compelled to offer attractive terms even on debt securities, in order to raise funds. 


\section{International Advanced Research Journal in Science, Engineering and Technology}

Vol. 8, Issue 6, June 2021

\section{DOI: $10.17148 / I A R J S E T .2021 .8643$}

- Investors have shied away from the equity market in the last few years due to various capital market scams. Attractive financial instruments are needed to lure these investors back.

\section{NEW FINANCIAL INSTRUMENTS}

Now we are going to discuss the financial instruments in detail

\subsection{Floating Rate Bonds}

The interest rate on these bonds is linked to a benchmark/anchor rate and is not fixed. It is a concept which has been introduced primarily to take care of the falling market or to provide a cushion in times of falling interest rates in the economy. It helps the issuer to hedge the loss arising due to interest rate fluctuations.

In India, the State Bank of India (SBI) was the first to introduce bonds with floating rates for retail investors. The SBI floating rate bonds were linked to the bank's term deposit rate which served as an anchor rate. The Treasury bill rate can also be the anchor rate. The interest rate is linked to the anchor rate as it reflects the economic indicators. The NSE Mibor is used now-a-days as the anchor rate for floating rate bonds.

To make this bond attractive to investors, the interest rate always has a fixed mark-up price over and above the anchor rate. In case of IDBI bond issues, the fixed mark-up was 2 per cent and the anchor rate was the 364-days treasury bill rate.

Floating rate bonds ensure that neither the borrower nor the lender suffer due to volatile interest rates. If the interest rate rises, the lender (investor) benefits, as he earns a higher interest and if the interest rate falls, it is advantageous to the borrower, as he can raise funds at a low cost.

FRB is an innovative instrument in a falling interest rate regime but it requires an active secondary debt market.

\subsection{Zero Interest Bonds}

Zero interest bonds require an active secondary debt market for attracting investors.

As the name suggests, there is no periodic interest payment and they are sold at a huge discount to the face value. These bonds benefit both the issuers and the investors by limiting funding cost when interest rates are volatile for the issuer and by reducing the reinvestment risk for the investor. Zero coupon bonds are sometimes convertible into equity on maturity which entails no outflow for the issuer, or into a regular interest bearing bond after a particular period of time. Companies such as Mahindra and Mahindra, HB Leasing and Finance have been pioneers in introducing these bonds in the Indian market.

These bonds are the best options for individuals and institutional investors who look for safe and good returns and are ready to hold them till the bond matures. Moreover, these bonds do not carry any interest, which is otherwise taxable.

\subsection{Deep Discount Bonds (DDBs)}

A deep discount bond is a zero coupon bond whose maturity is very high, say 15 years onwards and is offered at a discount to the face value. The Industrial Development Bank of India (IDBI) was the first financial institution to offer DDBs in 1992.

The issuers have successfully marketed these bonds by luring the investor to become a 'lakhpati' in 25 years. Moreover, these instruments are embedded with 'call' and 'put' options, providing an early redemption facility both to the issuer and the investor at a predetermined price and date. The issuer becomes free from intermittent cash flow problems and the funds can be deployed in infrastructure projects which involve long gestation periods.

Many variations of DDBs and zero interest bonds have come into the market. Some of them are as follows.

Zero Interest Secured Premium Convertible Bond The investor can convert his bond into an equity share at 30 per cent discount on average price at the end of one year. If the conversion price is lower than the face value, the issuer will redeem the difference. A similar option of conversion into two equity shares is available on the maturity of the bond. The bond may also have a warrant attached.

Zero Interest Fully Convertible Debenture The investors in these debentures are not paid any interest. However, there is a notified period after which, fully paid, fully convertible debentures (FCDs) will be automatically and compulsorily converted into shares. In the event of a company going for rights issue prior to the allotment of equity, resulting from the conversion of equity shares into FCDs, FCD holders shall be offered securities as may be determined by the company.

\subsection{Revolving Underwriting Finance Facility (RUFF)}

It is a 91-day debenture with two important, distinct features.

3.4.1 There is an underwriter (a banker or financial institution) who will be prepared to pick up the lot if it is not fully sold.

3.4.2 After 91 days, the stock will be rolled over, i.e., the debentures will be redeemed and reauctioned. Through this roll over, the debentures can be kept in the market for up to five years. If, at some stage, the money markets are tight and there are not enough takers for the issue, the underwriters step in and pick up the lot at a previously agreed rate. 


\section{International Advanced Research Journal in Science, Engineering and Technology}

Vol. 8, Issue 6, June 2021

\section{DOI: $10.17148 / I A R J S E T .2021 .8643$}

The treasury bill rate is the benchmark rate and a premium is added to it to attract the investors. The premium depends on the demand and supply of the 91-day instrument. The overall rate never exceeds the prime lending rate (PLR). This instrument is rated by a credit rating agency.

RUFF is beneficial to the issuers, underwriters, and investors. The issuer gets long-term funds at short-term rates, the underwriter gets a regular fee, and the investor gets a liquid debt instrument.

1.5. Auction Rated Debentures (ARDs)

It is a secured, redeemable (after 90 days), non-convertible instrument with interest determined by the market and placed privately with bids. ARDs are a hybrid of commercial papers and debentures. ANZ Grindlays designed this new instrument for Ashok Leyland Finance (ALF). This was a three-year instrument which had a zero coupon rate and was sold at a discount. The company repurchased the ARDs after three months of the issue and then re-issued them through fresh auctions. The interest rates were negotiated at quarterly auctions; this continued for three years. ALF raised Rs. 30 crore through this unique zero coupon instrument. ARD is technically a short-term instrument but it provides longterm finance for the company.

\subsection{Secured Premium Notes (SPNs) with Detachable Warrants}

This instrument is redeemable after a notified period, of say four to seven years. There is a lock-in period during which no interest is paid. The attached warrants ensure that the holder has the right to apply for and to be allotted equity shares, provided the SPN is fully paid. This conversion is done within the time limit notified by the company.

The SPN holder has an option to sell back the SPN to the company at par value after the lock-in period. If the holder exercises this option, no interest/premium will be paid on redemption. In case the SPN holder holds it further, he will be repaid the principal amount along with the additional amount of interest/premium on redemption in instalments as decided by the company. SPNs free the firm from the debt-serving costs in the initial years. TISCO and Bombay Dyeing were among the early issuers of SPNs.

\subsection{Non-convertible Debentures (NCDs) with Detachable Equity Warrants}

The holder of this instrument is given an option to buy a specific number of shares from the company at a predetermined price and time frame. The warrants attached to the NCDs are issued, subject to full payment of the NCDs value. There is a specific lock-in period after which the detachable warrant holders have to exercise their option to apply for equities. If the option to apply for equities is not exercised, the unapplied portion of shares would be disposed of by the company at its liberty.

Escorts, Bombay Dyeing, and Indian Rayon were among the early issuers of NCDs with warrants attached.

Secured Zero Interest Partly Convertible Debentures with Detachable and Separately Tradable Warrants

This instrument has two parts. Part A is convertible into equity shares at a fixed amount on the date of allotment. Part B is non-convertible, to be redeemed at par at the end of a specific period from the date of allotment. Part B carries a detachable and a separate tradable warrant which will provide an option to the warrant holder to receive an equity share for every warrant held at a price determined by the company.

\subsection{Fully Convertible Debentures (FCDs) with Interest (Optional)}

This instrument will not yield any interest for a specified short time period. After this period, FCD holders have the option to apply for equities at a 'premium' for which no additional amount is payable. This option needs to be indicated in the application form itself. However, interest on FCDs is payable at a determined rate from the date of conversion to the second/final conversion and equity shares are issued in lieu of the interest.

\subsection{Domestic Convertible Bonds}

These are hybrid securities that allow investors to separate the embedded equity portion from the bond and trade it separately. Because of the option to convert debt into equity, issuers can raise debt at a lower interest rate. These bonds were proposed by the Finance Minister in his 2008-09 budget speech to deepen the corporate bond market. However, this would require policy changes in different regulations and hence, the SEBI proposed an alternative instrumentNon-convertible debentures with detachable warrants. This instrument would help companies raise low-cost debt. It also allows the investors to detach the equity component from the instrument and trade on it.

\subsection{Collateralized Debt Obligations (CDO)}

CDOs are new in the Indian market and new products take time to gain market acceptance. However, with an increase in investor awareness and setting up of a regulatory framework, this instrument will be preferred by Indian banks and financial institutions in times to come. Collateralized debt obligation is securitization of corporate obligations such as corporate loans, corporate bonds, and asset-backed securities. Collectively, CDO consists of collateralized bond obligations, collateralized loan obligations, and credit linked notes that emanate from the same financial family. Banks and financial institutions use this instrument to meet regulatory obligations and to increase their revenues. Under the Basel Accord formulated in 1988 by the Basel Committee on Banking and Supervision, banks in most of the developed countries are required to maintain a risk-based capital of 8 per cent of the outstanding balance of commercial loans. These high risk-based capital requirements make the holding of commercial loans unattractive as the margins on these loans are also low. By securitizing loan portfolios, banks are not only in a position to trim their balance sheets but they are able to generate funds from these portfolios. 


\section{International Advanced Research Journal in Science, Engineering and Technology}

Vol. 8, Issue 6, June 2021

\section{DOI: 10.17148/IARJSET.2021.8643}

The structure of a CDO consists of multiple layers called tranches which are formed by pooling underlying assets. Each trench will have a pool of assets from corporate loans and bonds of similar seniority and maturity. These tranches are then rated by a credit rating agency and marketed.

These instruments offer higher yield to investors but the risk of default is high. Off-balance sheet financing has earned disrepute globally after the Enron fiasco. Many CDOs had Enron credit as part of their underlying exposure and these were defaults. This instrument is being increasingly used by European banks and the Bank of Japan besides American banks.

The ICICI Bank's first CDO issue failed to takeoff in March 2002 and was recalled because of unfavorable market conditions and lack of regulatory guidelines. In February 2004, the bank altered the product structure by bringing down the average maturity of the issue to around two years. The Rs. 100 crore CDO issue was mopped up by institutional investors. The ICICI bank sold corporate loans, given to 15 borrowers of varying sizes across 11 industries, through this issue to raise new assets as well as enhance exposure management in terms of specific sectors.

\subsection{Inverse Float Bonds}

These bonds are the latest entrants in the Indian capital market. Inverse float bonds are bonds carrying a floating rate of interest that is inversely related to short-term interest rates. The floating rate could be the Mibor (Mumbai inter-bank offer rate) or some other rate. If the Mibor falls, the return for the investor rises and vice versa. The actual rate payable on these bonds is arrived at by subtracting the floating rate from a fixed benchmark rate. Suppose the fixed benchmark rate is 12 per cent \& the six-month Mibor is 6 percent, then the interest rate payable on these bonds is 6 per cent (12-6). These bonds enable investors to earn high returns in a low interest rate environment. As interest rates are highly volatile, the investor has to observe the interest rate behavior carefully over the entire bond period, else he could end up getting a poor return. Thus, both the investor and the issuer have to hedge the interest rate risk. If the interest rates go up, the issuer benefits as the coupon rate of his bonds will decline in spite of higher interest rates.

Inverse float bonds were introduced in the US market in 1990. In India, the Aditya Birla Group, Grasim, and Hindalco issued inverse float bonds in August 2002. The Cholamandalam Investment and Finance Company Limited (CIFCL) were the first non-banking finance company to raise funds through the issue of inverse floaters.

\subsection{Perpetual Bonds}

They are debt instruments which do not have a maturity date. The investors receive a stream of interest payments for perpetuity. The bonds can be issued to retail investors with market making to ensure liquidity. The oldest perpetual bonds that continue to be in existence are those issued by the British Government no maturity date in 1814 to fund the Napoleonic wars.

In case of liquidation, holders of perpetual bonds are paid second last, after all other depositors and creditors but before equity shareholders. Being permanent in nature, they qualify as Tier I capital (i.e., equity and free reserves) of banks.

Another hybrid instrument similar to perpetual bonds is perpetual preference shares.

\subsection{Municipal Bonds}

They are debt securities issued by the municipal corporation of a city to raise funds for financing their growing investment needs for a host of infrastructure projects. The Indian municipalities need a sum of Rs. 28,500 crore to finance a number of basic projects. The financial health of municipalities is in a poor state. Till now, only the large municipalities were able to tap the market through issuance of such municipal bonds. Large municipalities issued bonds worth Rs. 1,500 crores. These bonds had limited appeal because the annual cumulative ceiling on municipal bond issues was a measly Rs. 150-200 crore and the tax-free status was available only for select issues. At times, these bonds were made saleable through government guarantee.

The Indian municipal bond market constitutes a mere 0.1 per cent of the total corporate bonds traded in India in contrast to the US municipal bond market which accounts for about 12 per cent of the total corporate bond market. The preference of Indian investors, including insurance companies and banks, to invest in securities with shorter maturity, regulatory restrictions on investment allocation, and a fewer number of tax-free bonds acts as constraints on the development of this market.

\subsection{Differential Shares}

Differential shares are shares with differential rights to voting and dividends. They are a class of shares which carry voting rights with varying rates of dividend. In fact, differential shares can be issued with no voting rights but high dividends or, with varying rights and dividends. If the voting right of the shareholder is taken away, the shareholder is compensated by higher returns. This concept originated in Canada and was highly successful. This concept was introduced in India through the Companies (Second Amendment) Act, 2000. According to this law, a company can issue shares with differential rights 'as to voting or dividend or otherwise.'

Companies are now allowed to issue shares with differential voting rights including non-voting shares, to the extent of 25 per cent of the total share capital, provided, they had profits that could be distributed, in the preceding three years. However, companies will not be allowed to convert their equity capital, with regular voting rights. Into shares with differential voting rights and vice-versa. 


\section{International Advanced Research Journal in Science, Engineering and Technology}

Vol. 8, Issue 6, June 2021

\section{DOI: $10.17148 / I A R J S E T .2021 .8643$}

Differential shares are positioned between ordinary equity shares and preference shares. The preference shareholders are entitled to certain assured dividends but no voting rights while ordinary equity shareholders have voting rights in proportion to the number of shares held but are not entitled to any assured return.

\subsection{Securitized Paper}

It is a popular fund-raising technique in the developed markets such as the US and the UK. Asset securitization began in the US in the 1960s with the pooling of residential mortgages. Now, this concept extends to a whole range of financial assets such as receivables and mortgages held by businesses and financial firms.

Securitization is a process by which a company raises money by selling off its receivables. These receivables are sold off to cash-rich investors by converting them into securities. The receivables are sold at a discount to the investors which represent the yield. In securitization, the assets to be securitized are identified on the basis of their creditworthiness.

Factoring is quite similar to securitization as the factor buys the receivables of a company at a discount. However, there is no rating or creation of a secondary market in factoring. Moreover, factoring has evolved as a trade financing tool rather than for medium-or long-term financing.

\section{CONCLUSION}

There are a lot of financial instruments, but each financial instrument serves the purpose and needs of an investor. All the above new instruments have a potential large market. To market them effectively, the issuers and the government agencies need to increase investors' awareness, make legal amendments wherever necessary, and list them on the NSE to increase liquidity and depth of the Indian financial markets.

\section{REFERENCES}

[1]. Tufano, Peter. (1989). "Financial Innovation and First Mover Advantages." Journal of Financial Economics, 25, 213-240.

[2]. Levine, Ross. (1997). "Financial Development \& Economic Growth: Views and Agenda." Journal of Economic Literature, 35 (June), $688-726$.

[3]. Duffie, Darrell and Rohit Rahi. (1995). "Financial Market Innovation and Security Design: An Introduction." Journal of Economic Theory, 65 (February), 1-42

[4]. Karunal, Ch. \& Rukmini, M. "EMERGING TRENDS IN FINANCIAL INNOVATION TOWARDS NURTURING THE GROWTH OF INDIAN ECONOMY". ICRIESHM pg. 491-498.

[5]. Chandrashekar, Y. (2001), 'Collateralised Debt Obligations,' Chartered Financial Analyst, November, pp. 37-40.

[6]. Chandrashekar, Y. (2001), 'Differential Shares,' Chartered Financial Analyst, June, pp. 16-18.

[7]. Ross, Tom (2002), 'Why Not Securitise,' ICFAI Reader, July, pp. 53-56.

[8]. 8. Srikant, V. and Prabhavathi Rao (1998), 'Assets Securitisation: Needs Backing,' Analyst, August, pp. 36-37.

[9]. Prasuna, D. G. (2002), 'Inverse Floaters: Wooing Investors?' Chartered Financial Analyst, October, pp. 25-28.

[10]. Reserve Bank of India, Report on Currency and Finance. 